\title{
Fans for diversity? A Critical Race Theory analysis of Black, Asian and Minority Ethnic (BAME) supporters' experiences of football fandom
}

\author{
Stefan Lawrence \& Christian Davis
}

This is the authors' copy of Lawrence, S. \& Davis, C. (2019): Fans for diversity? A Critical Race Theory analysis of Black, Asian and Minority Ethnic (BAME) supporters' experiences of football fandom, International Journal of Sport Policy and Politics, DOI: 10.1080/19406940.2019.1627481 


\title{
Fans for diversity? A Critical Race Theory analysis of Black, Asian and Minority Ethnic (BAME) supporters' experiences of football fandom
}

\author{
Stefan Lawrence and Christian Davis
}

\begin{abstract}
Over the last 20 years or so there has been a proliferation of anti-racist organisations, campaigns and interventions across football at all levels, allied to broader social, cultural and political shifts in late modern digital societies. Indeed, relying on certain statistical data, which reports a decline in racist incidents in stadia, might lead many anti-racist policy-makers to champion liberal doctrines and to proclaim football fan cultures as quantitatively 'less racist'. However, in this article, using Critical Race Theory as a guiding theoretical framework, throughout, we foreground the qualitative experiences and stories of BAME football fans to understand why football fandom and spectatorship remain predominantly 'White' activities. Using semi-structured interviews and observational techniques, we explore critically the continued significance of 'race' as a mediating factor in football fandom, how BAME football fans negotiate-resist belonging in football fandom cultures and the implications of BAME fans' testimonies for policymakers. We conclude by arguing for an increase in intersectional research across football/football fan studies, to understand better the racialised aspects of football fandom, and we also urge scholars and policymakers, alike, to place greater emphasis on 'trust building' innovations, as opposed to 'diversity', given the latter has taken on a commercial value of late.
\end{abstract}

\section{Introduction}

Football or soccer has long been a part of the social fabric of many societies by way of its ability to unite peoples and communities fractured by cultural and ethnic differences (Mahony and Howard 1998, Beccarini and Ferrand 2006, Kidd 2008, Darnell 2010, Donnelly et al. 2011, Biscaia et al. 2012, Karakaya et al. 2016). What is less often acknowledged, at least by those who profess uncritically 'the power of football', is that sporting communities, especially those formed by and through a collective love of a particular club or team, rely fundamentally on the notion of exclusion in order to function. Not only does the notion of 'belonging' to a particular nation, club or fandom rely on an 'us-them dualism', intra-group politics, power struggles and discourses of 'authenticity' serve to exclude certain members and divide communities internally (Crawford 2004, Lawrence 2016). The now broad corpus of research into football fandom, and its representational power (see Bale 2000) reveals it can never be the case that football is either entirely inclusive or exclusive. 
This is an Accepted Manuscript of an article published by Taylor \& Francis in International Journal of Sport Policy and Politics on 17/07/2019, available online: http://www.tandfonline.com/10.1080/19406940.2019.1627481.

Cashmore and Dixon (2016, p. 5) note that football in the twenty-first century has transformed itself from a 'white working-class man's sport . . to a multi-ethnic, polylingual extravaganza that is available to all'. Lawrence (2017) has suggested this shift has coincided with football's (neo)liberal turn, which, since the early 1990s, has helped enable an increase in Black male professional players and the advent of a number of organisations and policy directives that champion anti-racism. Importantly, while not denying some positive outcomes have accrued from a change in policy agendas since the adoption of liberal principles, he also advises caution when advancing claims football is now 'inclusive', given there is still ample evidence to suggest Black, Asian, and Minority Ethnic (hereafter: BAME) people still experience barriers to participation in a number of different areas of the game (Burdsey and Randhawa 2012, Cleland and Cashmore 2014, Ratna 2014), but especially football fandom. Here we note, by using the term football fandom, during this paper we are referring to the processes through which individuals and groups perform devotion and/or claim affiliation to a particular professional football club.

Throughout this paper then, we are concerned with: (1) exploring critically the continued significance of 'race' and racism in football amidst the establishment of an anti-racist policy environment; (2) how BAME football fans perceive/experience participation in football fandom (see also Carrington and McDonald 2002, Burdsey 2006, Kilvington 2016); as well as (3) the implications of this for those involved in sport/football governance and policymakers. We choose to foreground the experiences of BAME fans, throughout this paper - as opposed to narrowing our focus to, for instance, British South Asian (hereafter: BSA) or Black fans - given (a) it is a term commonly used in policy and strategy documents in football/sport; and (b) there is political value in emphasising how BAME fans, as a collective, experience the outcomes of institutional and individual modes of oppression in similar ways. This is not to deny different ethnic groups experience racism(s) and exclusionary practices differently; however, documenting these nuances is not the focus of our paper for the reasons outlined above.

\section{Critical Race Theory, whiteness and football fandom}

CRT has gathered traction in the critical sociology of sport in recent years, as both theoretical framework and as methodology, owing much to the pioneering scholarship of Kevin Hylton (2005, 2018) in the area. At risk of oversimplification, Harris et al. (2015, p. 1) defines 'CRT . . as a study of hegemony', which exposes the irrationality of dominant liberal politics and its emphasis on 'meritocracy' and 'the rule of law'. Liberalism purports to strive for the equality of all people (Kernohan 1998, p. 2) and that 'hard work merits reward' (Ramsay 2004, p. 71), yet CRT contends it fails to recognise that existing social systems preserve the status quo and perpetuate racialised hierarchies (Kymlicka 2013). For Hylton (2005), major sport organisations and sport policymakers have adopted these principles as guiding mantras and thus liberalism shapes heavily the current policy environment in which sport operates. There have been a few applications of CRT to football, namely because it is a framework that has proved useful for critiquing any institution that has adopted liberal doctrines of supposed 'race neutrality', white supremacy (see Lawrence 2017), colour-blindness and the prevalence of mircroaggresions (see Burdsey 2011). In order to extend the application of CRT to the study of football further, and specifically to football fandom, we follow Delgado and Stefancic (2000) and some of their basic tenets of the framework to appraise some of the relevant literature, namely: the notion racism is endemic (and not occasional); whiteness as dominant discourse through which much mainstream culture is experienced; and, the elevating of BAME people's voices and testimonies.

Literature on 'race' and football is now more widespread than ever before (Hughson et al. 2016); however, much of this literature has focused on BAME peoples' experiences of playing football, while their spectating practices and participation in fandom remain relatively under-researched (Long et al. 2009). As De Kosnik and Carrington (2019) note vis-à-vis the field of fan studies in general, there is a need to explore fandoms of colour, not only to explore what it means to a BAME 
This is an Accepted Manuscript of an article published by Taylor \& Francis in International Journal of Sport Policy and Politics on 17/07/2019, available online: http://www.tandfonline.com/10.1080/19406940.2019.1627481.

football fan but, more tellingly, to explore the role of BAME fans in the cultural production of football fandoms. Further research into this is warranted given during the 2018/2019 English league season there has been a spate of high-profile incidents (e.g. a White Tottenham fan throwing a banana at Gabon striker Pierre-Emerick Aubameyang during the North London derby; four White Chelsea fans being suspended after appearing to shout racist abuse at Manchester City's Raheem Sterling during a game; and, a video circulated on the Internet depicting Millwall fans singing 'I'd rather be a Paki than a Scouse'), which suggests a resurgence in 'old' bigoted forms of colour racism at football matches.

Previous research had observed that overt forms of racism and racist violence in football stadia, initiated by football fans typically on the far-right, was seemingly in decline in the 2000s (Kassimeris 2007, p. 86), leading to what some have interpreted as a more 'sanitised' and less violent fan culture (Cleland and Cashmore 2016). However, this 'decline', owing in some part to a number of anti-racist campaigns - Fans for Diversity, a joint initiative launched in 2014 and run by the Football Supporters Federation and Kick It Out, being one such example in England - has not naturally translated into a significant increase in BAME fans on the terraces at men's professional games. Therefore, given Burdsey and Randhawa (2012) note BSA communities, for instance, have a high level of interest in men's professional football, especially watching games on television and/or purchasing club merchandise of their favourite team, it is reasonable to query why this interest has failed to translate representationally into attendance at matches. Similar then to an absence of BSA people playing the game at elite level and BAME people engaged in coaching roles (Burdsey 2004, Ahmad 2011, Ratna 2011, Bradbury et al. 2018), the amount of BAME fans attending stadia warrants scrutiny.

Football stadia remain overwhelmingly White male spaces (Burdsey and Randhawa 2012; Cleland and Cashmore 2014, Gibbons 2016) and, more broadly, Long and Hylton (2002, p. 97) have suggested that spectating sport, in general, is perceived as a 'white experience'. Lawrence (2016), in the context of exploring fandom at Walsall FC, therefore, has attempted to understand this by focusing on the instrumentality of whiteness discourses in local-spectator communities and how they are used to express 'authenticity' and negotiate 'belonging'. For Lawrence, the repetition and rehearsal of historical tropes of a regionally contingent form of whiteness (as well as workingclassness and masculinity) are central to the ways in which White male fans perform football fandom. This form of 'collective remembering', which is often linked to cultural practices, that are historically rooted and racialised as White (such as drinking beer and Bovril, eating savoury meat pies, regional dialect, singing of terrace chants traditionally taken from mainstream popular culture racialised as White), helps reproduce football terraces as White spaces - or communities reminiscent of a 'time before colour'.

Importantly, fandom practices such as those above are not thought consciously to be 'White' and thus are not discussed as though they are racialised; they merely are. This, what we understand as, 'colour-blindness' is an important mechanism in the continuation of racialised structures in covert and (un)intentional ways (Solórzano 1998). Colour-blindness teaches people to ignore or deny colour, meaning many in football are blind to how racialisation shapes and constrains participation in football fandom; thus, if this is indeed the case, they are unlikely to understand that football fandom is racialised or perceive there to be a problem.

It would, however, be disingenuous not to acknowledge some of the successes of liberalism. Indeed, liberal policies of inclusion and diversity have had an impact and have enabled football to become more of a multiethnic sport in Britain (Martinez and Mukharji 2013), which is why it is perhaps difficult for some to 'see' the effects of racialised forms of exclusion. Kilvington (2017) reminds us that any exploration of football fandom and stadia on match days must be approached with a degree of nuance given there are limited examples of BAME fan groups being formed across England. For instance, although BSA fans remain underrepresented, fan groups with strong ethnic identities such as Bangla Bantams and Punjabi Wolves have emerged in recent years. Evidence of South Asian influence on football fandom might even be seen as evidence of a coming hybridisation. Whether it is the 
This is an Accepted Manuscript of an article published by Taylor \& Francis in International Journal of Sport Policy and Politics on 17/07/2019, available online: http://www.tandfonline.com/10.1080/19406940.2019.1627481.

availability of chicken Balti pies or the playing of bhangra music before some matches or at half-time, this does suggest productive dialogue and the fluidity of football fandom over time.

Unquestionably, anti-racist legislation and campaigns have facilitated the proliferation of the game amongst BAME communities (Long et al. 2009). In light of this, Carrington (2004, p. 3) outlines neatly the challenge we take up in the rest of the paper:

... we need to avoid the twin dangers of the sentimental conservatives, who believe that the mere fact of white fans singing the names of black athletes demonstrates the end of racism, as much as we do against those pessimistic commentators who dismiss any shifts within the realm of the popular as merely ideological.

Surprisingly little attention has been played to the racialised aspects of football fandom and thus the policy debate is lacking an empirical evidence base. It is now 20 years since Carrington (1998) wrote about the rise of the phenomenon of 'New Laddism' as a form of masculine identity, embodied by (mainly White) football fans, which celebrated sexist, homophobic, xenophobic, and racist attitudes, by passing off malicious actions as light-hearted banter. However, his call to seriously consider the racialised aspects of football fandom has not been taken up by many although the literature on football fandom has proliferated.

\section{The research}

In order to identify suitable participants, purposive sampling was used as it best enabled the researchers to answer the primary research questions (Adler and Clark 2014). Moreover, it was also useful in that it allowed the researchers to seek out an often 'hidden population' (Monette et al. 2013, pp. 154-155) of football fans. The inclusion criteria for the study therefore dictated that only those who identified as Black, Asian or minority ethnic and as 'football fans' were interviewed (Singh and Nath 2006). By 'football fans' we refer broadly to a variety of fan-types such as 'media consumers', 'casual fans', 'regular attenders' and 'fanatics' (Tapp 2004, p. 396) of the men's professional game. Researchers utilised personal contacts and approached potential participants either face-to-face at matches or via telephone: 14 people thus agreed to participate in semistructured interviews. All interview participants resided in the West Midlands of England, identified as either lower middle-class, or working-class (Andersen and Taylor 2008) and as either Black (Black British, Black African-Caribbean, Black African, Mixed or Black) or South Asian (British Asian, Indian, Pakistani, Bangladeshi). All but one interviewee was male. All fans were given pseudonyms and regarded themselves as 'football fans': five participants Lee, Nathan, Conroy, Claire and Darren, were regular attenders and fanatics, who held season tickets at their favourite clubs and attended every game; one participant, Sean had complete access to all home games due to being employed by his favoured club and attended regularly; the remaining eight participants Sunny, Jason, Ryan, Raj, Femi, Jagdeep, Aaron and Reece were more sporadic match-goers, casual fans and media consumers, attending depending on work patterns and other priorities.

The interviews were all circa $45 \mathrm{~min}$, recorded digitally, transcribed verbatim and coded. Semistructured interviews were appropriate for investigating the racialised experience of football insofar as they complement a CRT approach. Solórzano and Yosso (2002, p. 26) suggest that recording 'lived experiences' marries well to storytelling, and the value it places on experiential forms of knowledge. These stories, which give voice to BAME fans, act as a form of counter-hegemony (Delgado and Stefancic 2000; Hiraldo 2010).

Secondly, participant observation was also used, which involved interpretations of behaviour as data (Becker 1958). Ten football matches (three during 2017/18 season and seven in 2018/19 season) were attended across three different tiers of the English Football League. All of the clubs were based in the West Midlands of England. The different levels at which the teams played are important due to the size of the crowds and the extent to which the clubs have experienced commercialisation (Lawrence 2016; Lawrence and Crawford 2019). A research diary was kept by both researchers to record the racialised aspects of the crowd and environment, such as the ethnic 
This is an Accepted Manuscript of an article published by Taylor \& Francis in International Journal of Sport Policy and Politics on 17/07/2019, available online: http://www.tandfonline.com/10.1080/19406940.2019.1627481.

demographics in stadia, the atmosphere within and around stadia, and interactions expressed through verbal and non-verbal gestures (see Wilhelm 2018). CRT was used as a guiding framework throughout this phase which meant that we were sensitised to instances of microaggressions (Solorzano et al. 2000, p. 60), cultural practices racialised as White, liberal approaches to equality and tradition to enhance our findings. Passive observation was used (DeWalt and DeWalt 2011), and in accordance, notes were taken on a mobile phone to keep discreet and preserve a natural setting (Taylor et al. 2015). The field notes were then placed alongside data from the interviews and it too was coded, thematically.

\section{'Race' at the intersections of socio-economic status}

We wish to begin the analysis by pointing out that BAME fans share a common complaint made by the majority of football fans. That is, participants commonly reported that the time and money needed in order to go to a game was often beyond their individual circumstances. Despite being passionate about football and willing to spectate, Raj (a 28-year-old, South Asian Indian, third Generation British born, who is a sporadic match-goer), Femi (a 39-year-old, Black African (Nigerian), Born in Lagos, who moved to England in 2003 and whose attendance has declined since becoming a family man) and Sunny (a 29-year-old, South Asian (Bangladeshi), second generation, British born man who is a previous season ticket holder) all bemoaned socio-economic factors prevented them from going to games more regularly:

RAJ: In terms of going to games, I definitely come from a pretty poor background so it's never been likely for me to afford to go to a Premier League game. Even though I'm an adult now, it's still ... I have too much responsibilities, like when you begin working; because of the area that I come from, more gets taken out of your pay packet than you would ever anticipate, so you have got too many outgoings to afford a luxury like going to a game.

FEMI: Cost is a barrier because a lot of people from ethnic minorities are maybe first, second, third generation of living here so they might not be as established as they would like to. So in terms of spending money on entertainment, it may not be such a priority and they could go to local sports clubs, pubs etcetera to watch the football very much cheaper; they could sit down with their family for less than the price of one ticket so I would definitely say that cost is a factor.

SUNNY: I would say that sometimes the tickets are rather expensive, and if you are in an area which is more poverty-stricken sort of thing, then you cannot afford . . . some people cannot afford to live, let alone to go and watch a football match.

It was not uncommon for participants to report being priced out of going to games and/or that family and work commitments were also major barriers. As is well documented, the hypercommercialisation of football has transformed it (Horne et al. 1999, p. 250) from a game traditionally played for minimal financial gain (Collins 2013, p. 14-20), to a 'corporate quest for profit' (Staurowsky, cited in Slack, 2004, p. 143). What is clear from the testimonies above is that Englishbased football fans with less disposable income are being replaced by new more affluent spectators (Giulianotti 2002, p. 25-46). As seminal theorist of 'race' and ethnic studies, Paul Gilroy (1998), notes in certain moments identity politics must not take priority over the most pressing task for scholars of the late capitalist moment, which must be to tackle poverty, and socio-economic deprivation whomever it concerns. Here, offering a more conventionally Marxist analysis must not be seen as anathema to CRT (Barak et al. 2010, p. 23) as we contend, as does Cole (2017), it is useful to enrich CRT's effectiveness.

While we assert the utility of a class-based analysis, we are however moved here to avoid a 'reductionist economist' stance (see Bakan and Dua 2014, p. 5), which ignores the importance of other forms of self-identification (Allahar 2005) and overlooks how 'poverty and race intersect in complex ways' (Delgado and Stefancic 2000, p. 124). And so, by reading this testimony through a 'race' conscious approach, the above testimonies ask us to recognise that the experience of socioeconomic deprivation is in many cases a racialised one. BAME people, for example, are more likely 
This is an Accepted Manuscript of an article published by Taylor \& Francis in International Journal of Sport Policy and Politics on 17/07/2019, available online: http://www.tandfonline.com/10.1080/19406940.2019.1627481.

than White people to experience a poorer quality of life and overall socio-economic deprivation (Equality and Human Rights Commission 2008, p. 62), more likely to have never worked or to be long-term unemployed (Census 2011), more likely to be in persistent poverty (Race Disparity Audit 2017), more likely to live in deprived neighbourhoods (Martone 2008, p. 91), and receive substandard education compared to the general White population (Eden 2017, p. 57-65). Moreover, Hartlep (2011, p. 52) explains that because of these circumstances and the stigma of indolence, BAME people frequently work low-paid jobs. Thus, 'race' remains a key analytical component for understanding socio-economic inequality (Ladson-Billings and Tate 1995).

To this end, and importantly for this paper, one part of the explanation for the relative lack of BAME fans in football stadia and fan communities across England is because BAME fans are less likely to be in a financial position to buy a ticket for themselves or their families than White people. This is certainly not to deny some White people do not encounter financial obstacles, too. However, it is to argue that given BAME people often also refuse/lack the cultural and/or bodily capital needed to properly feel as though they 'belong' in/around football stadia (a theme which we highlighted earlier on in the paper and one we will extrapolate in the following sections), a lack of economic capital both prevents physical access to the game and, in turn, makes developing other forms of capital associated with match-going (e.g. building social networks and/or learning/ appropriating the dominant culture) more difficult.

\section{A different take on the 'carnival': the experience of matchday from a BAME perspective}

This concept of football as carnival has been developed over the years by numerous scholars (Hoy 1994, Giulianotti 1999, Turner 2013, Edensor 2015). Much of this research has rightly sought to reclaim and reframe discourses of football fandom as boisterous but jovial and celebratory, distancing it from the hooligan trope perpetuated by mainstream media since the 1970s. Indeed, as Cleland and Cashmore (2016, p. 123) note, many fans report 'a more sanitised and gentrified culture emerging out of measures introduced since the 1990s (including changing police strategies, banning orders, alcohol bans, higher ticket prices, and CCTV)'. We are keen here though to document the perspectives of our participants whose testimonies require us to point out how 'race' inflects how the 'matchday carnival' is experienced. That is because many of our participants reported feeling as though they might be targeted if they joined in matchday festivities. In some cases, the fear of hostility or even physical violence, influenced some fans not to attend games regularly. For Sunny and Darren (a 30-year-old, Black African-Caribbean (Jamaican), second generation British born, male and current season ticket holder at Wolverhampton Wanderers):

SUNNY: [considering a] stereotypical point of view [and] what happens at these football games, I know some Indian friends of mine, and also Jamaican [sic] friends that they won't go to football matches because they know about the chants that go on. They don't want to be taking or putting themselves in harms-way because they don't want to get hurt, they don't want their family at risk, but also, they don't want to feel the emotional burden when people are throwing bananas or shouting discriminative things ... what if I had a child with me at the game? And hearing all of this racial abuse, I don't think it is very ... it's not a constructive thing for a child to hear.

DARREN: I know if you really want to do it [go to football matches], no matter what culture you are, you can do ... but I can see how someone of an ethnic minority can feel like they couldn't, definitely.

And so, while statistical data may lead anti-racist policymakers to champion football as quantitatively less racist and discriminatory, these testimonies suggest this is not the qualitative experience for some BAME fans interviewed during this study.

To further this point and to support the notion that overt racism is still evident, while attending an English Football League (EFL) match as part of this project, one of us witnessed a chant instigated by five or six people of 'he's got a pineapple on his head', which was directed at a Black player wearing dreadlocks - the same chant that Jason Lee had been subjected to 20 years prior (see Carrington 1998). Moreover, while attending another EFL game, one of us observed a fan 
This is an Accepted Manuscript of an article published by Taylor \& Francis in International Journal of Sport Policy and Politics on 17/07/2019, available online: http://www.tandfonline.com/10.1080/19406940.2019.1627481.

shout at a Black player 'come on you WOG'. Many fans showed tacit approval by turning and laughing. Both chant and comment were clearly audible and went unchallenged by the chiefly White male fans on the terraces. Leddy-Owen (2014, p. 1129) writes that some White people feel that BAME groups are perceived to be unsettling the imagined harmony of all-White spaces and are fearful that they may be 'overrun'. From this perspective, actions such as those above may well be understood as deliberate and hostile behaviours, designed to deter BAME fans from entering chiefly White male spaces.

Nathan (a 27-year-old, of mixed Black African-Caribbean (Jamaican) and White British descent, second-generation British born, and current season ticket holder at Wolverhampton Wanderers), however, was more relaxed about the experience of being inside stadia. For him, there are other aspects of the matchday experience that made him feel apprehensive:

In the ground [you're] pretty safe, I mean there is a lot of stewards and police, CCTV, so you are quite safe; obviously you may get a few missiles thrown at you but generally speaking outside of the ground it is a different kettle of fish.

Nathan, here, echoes what previous research has suggested vis-à-vis the sanitisation of fandom in stadia; however, his willingness to distinguish between the experiences of being inside and outside stadia, on matchdays, in close proximity to kick off is telling. Sunny, too, spoke to these differences:

SUNNY: You get a lot of - excuse my language - you get a lot of piss heads that are just drinking before the game and then what happens is they seem to get a bit carried away and I think that their emotions might run through ...

Raj provides an example of one such instance when one group of mainly White fans got 'carried away':

When they first got promoted to the Premiership we was out watching it at the pub ... and obviously we was just happy because they had got promoted, so we went out to go and get a pizza for a celebration ... we was going through town and there was about 150 fans just walking down the street, and we was like "this is great" to them celebrating and that. Then they surrounded the car and started rocking the car . . . at the time we thought "it's just banter, they're just having a laugh", and then a few of the fans smashed the windows ... we just had to drive through the crowd but yeah they was shouting racial slurs and that ... my youngest uncle, he wears a turban and that so I don't know, that might have had something to do with this, I don't know.

According to Robson (in Munt, 2000, pp. 219-225), it is often the case that an emotional connection to a specific football club is found through familial or local ties. Given Raj is born and raised in the same city as the fans in his testimony he too reports his fondness for the club is born out of locality. He feels that he has the right to celebrate his city's victory because of traditional beliefs about football fandom being about geography. It is this fondness or desire to belong that, at first, leads Raj to explain the smashing of his car's windows as 'banter' and over-exuberance. After hearing 'racial slurs' though it is clear that he felt ostracised, as if it was not 'his' victory to celebrate despite the enduring myth that 'real' football fandom is about supporting the local team. Raj's testimony relates to what Ahmed (2000) terms feeling like 'a body out of place', which she uses to describe those moments when a person becomes conscious of their Otherness. This sense of feeling out of place is confounded by a lack of what Howard (2008, p. 963) understands as 'Whiteness as property'. In spaces where White people are the norm, if an individual is unable to pass as phenotypically White, because 'race' remains a central organising principle of society, they are categorised as Other (Harris 1993, p. 1734). This can lead BAME fans to feel excluded. The critical point to be taken from Raj's testimony then is that, whether or not the 'racial slurs' and the 'smashed ... windows' were linked, Raj makes this link, meaning the sense of communion he felt with other fans was short-lived.

The testimonies discussed above are emblematic of a struggle to belong. The matchday rituals associated with live spectating, both before and after the game, were cited by participants as being just as important factors as the practices of fans inside stadia, if not more so. Rituals that White fans consider 
This is an Accepted Manuscript of an article published by Taylor \& Francis in International Journal of Sport Policy and Politics on 17/07/2019, available online: http://www.tandfonline.com/10.1080/19406940.2019.1627481.

benign or insignificant can resonate differently or far more deeply with BAME fans (De Kosnik and Carrington 2019). Moreover, while participants believed overt racism in football stadia to be infrequent when compared to football in the 1970s and 1980s (Cashmore and Dixon 2016, p. 55), it has not disappeared. The testimonies from our participants, therefore, suggest that the concept of football fandom as carnival or as sanitised need pay closer attention to the social positionality of precisely who it is that feels that way. This is not to say of course that all football fans are White, male, ignorant, violent and racist. It is also not to say that aspects of football fandom are not 'carnivalesque', nor that many White fans condone overtly racist behaviours; however, it is to recognise that 'race' remains a significant medium through which perception is generated and belonging is negotiated.

\section{BAME football fandom as 'critical consciousness'}

Despite differing reservations about going to games, it was evident throughout the sample that a passion for football endures amongst BAME fans, which swayed many of those individuals who complained about being priced out of football, or who reported feeling fearful, to make financial sacrifices in order to attend. We must draw from this that BAME fans can and do negotiate belonging in football fandom; however, the critical question here must be how this is negotiated, given a number of interviewees expressed concerns about racism continuing to operate as part of football fan cultures. Conroy (a 24-year-old, Black African-Caribbean (Jamaican), third generation British born male and a current season ticket holder at West Bromwich Albion), for instance, is conscious of how racism is often expressed in different forms and was keen to tell us about, what scholars of 'race' and ethnicity would term, 'backstage racism' (Picca and Feagin 2007, p. 91):

With the past and the hooligans ... in the 70s and that, when John Barnes was playing football and all [the racist abuse] that he went through, you know what I mean? . . obviously it has calmed down but in the back of our heads we know it's still there ... definitely back in the day, racism, you could just say it how it is and say it to their face, and they cannot do anything about it ... but it is more undercover now, undercover racism, so it has calmed down, but it is behind your back now.

Backstage racism is a hidden form of racism present typically in all-White, private, social spaces. A trust, often emanating from myths of ethnic sameness, has led to the 'backstage' space being marked as a 'safe' place to express overtly racist views without the risk of being vilified or exposed publicly as 'a racist' (Picca and Feagin 2007, p. 96-100).

In light of the slippery nature and unpredictability of contemporary racisms, Yosso (2005) stresses that many BAME people avoid spaces perceived to own the potential for racialised conflict - as evidenced by Sunny (in the previous section) and Conroy. Through a parent's experience of oppression, storytelling can be used as a conflict management tool. Zamudio et al. (2011, p. 39) add that these stories are passed down to teach resilience, which creates a 'critical consciousness' where the receivers (read: the younger generations of BAME peoples) develop an understanding and awareness of structural oppressions. Out of some BAME fans' 'critical consciousness', sharpened when at football matches, came discussions unlike those seen in previous research with White football fans:

REECE: Well it depends on the situation ... plenty of times I've been in scraps. You aren't calling me or one of my mates a black bastard or something like that yeah, and thinking that you're going to get away with it.

CONROY: Well I know violence is not the answer, it's not the way, and so I do not tend to work myself up about it because if you're racist then that just means that you're uneducated and you do not really know, so I tend to just walk away or talk to someone at a higher position.

The cultural artefacts passed down from one generation of BAME fans to the next, were just as likely to be of coping or avoidance strategies and stories of racialised resistance as they were about the importance of rivalries or historical figures from club folklore. On the one hand, Reece's (a 19-year-old, mixed Black African (Ghanaian) and White British descent, third generation British born, male, who is a casual matchgoer) advocates for a 'by any means necessary' approach when confronted by racism. On the other hand, 
This is an Accepted Manuscript of an article published by Taylor \& Francis in International Journal of Sport Policy and Politics on 17/07/2019, available online: http://www.tandfonline.com/10.1080/19406940.2019.1627481.

however, Conroy advocates for a form of 'conformist resistance' (Solorzano and Bernal 2001., p. 318), which is committed to a calmer, more erudite response. In light of such testimonies, it seems reasonable to suggest that the emergence of BSA fan groups (see Kilvington 2017) is in part because individual BSA fans feel more at ease amongst others they read as ethnically similar when entering what remains, a largely white, working-class, male space.

Other BAME fans, however, preferred to forego live spectating altogether and lived their love of particular club from afar, through media. Because BAME fans' experiences of the West Midlands context, for some of our participants at least, meant they did not feel entirely comfortable being present on terraces, some participants preferred to find sporting refuge at different city's football clubs. Many participants supported successful men's football clubs from London or the North West of England, despite living several dozen miles away. Jagdeep (a 25-year-old, South Asian (Indian), second generation British-born, man who attends between ten and fifteen games per year) explains:

JAGDEEP: It's so expensive driving down to London and watching it [the games], especially with some of the London clubs [the supporters] get priced out of the game [in] this day and age, so I do watch a lot of TV football you know. I watch Midlands football when I'm up and about, I will go and watch Wolves and that if I'm around, but yeah Arsenal I would say that they are the team that I follow.

Femi, too, has a fondness for Arsenal:

FEMI: For me, when they have the [camera] shot of the crowd, I always try to look at the ethnic diversity that's in the crowd. So obviously Emirates Stadium is quite a big stadium, and also we know that in London a good majority of ethnic minorities support Arsenal so I look at that and I think 'ok I know that there's so many people that support Arsenal from ethnic minorities; does it represent what I think would be the amount of people that would go to the stadium?' And I would definitely say since they have moved from Highbury the number of ethnic minorities has increased ... also depending on where they live because as we've discussed earlier, a lot of ethnic minorities might support Manchester United but they don't live anywhere near the towns that they represent, so travel might be a factor as well.

Femi's testimony, especially, illustrates that his decision to align himself with Arsenal is, to a large extent, because he sees his(racialised)self reflected in the crowd and not directly as a consequence of 'deterritorialisation' processes, impelled by hypercommericlisation nor 'collective memory' and familial labour histories. To this end, adopting a CRT perspective has allowed us to reread the existing literature on contemporary football fandom and to illustrate that it has failed to properly document voices like Femi's when attempting to understand the notion of 'supporting from afar' and/or that, in some instance, certain fandoms might be the result of racialised traumas, oppressions or media representational strategies. Stated differently, we might then conclude that attempts to conceptualise football fandom have, themselves, been colour-blind.

\section{Conclusion}

Over time, English football has transformed itself on a number of levels from a sport dominated by white working-class men, to an institution encompassing many ethnicities, nationalities and cultures. However, while liberal doctrines have shaped anti-discriminatory practices, policy environments and governance cultures across sport, according to the testimonies above, they have, nonetheless, failed to encourage representational numbers of BAME fans into football stadia. This paper, therefore, has three major contributions: (1) it highlights that the quantitative reduction in reports of racist incidents in football is at odds with the qualitative data in this paper; (2) the current cultural and policy environments shaping and governing football fandom have not changed significantly the perceived risk of violence or racism at football matches, at least for a number of BAME fans interviewed in this study; and, (3) the policy environment and the experiences of people they are serving are currently eschewed, given BAME fans still report the same fears as were associated with football decades ago. To be clear we do not deny some successes of anti-racist/liberal policy or supporter-led innovations, and we have not sought to 
This is an Accepted Manuscript of an article published by Taylor \& Francis in International Journal of Sport Policy and Politics on 17/07/2019, available online: http://www.tandfonline.com/10.1080/19406940.2019.1627481.

single out any one campaign or intervention in particular during this paper, but we are suggesting that fresh policy approaches need to be forthcoming to respond to ongoing concerns.

We recommend that scholars, policymakers, professional clubs or fan-led interventions might counter social imbalances in football by reframing the phraseology of 'diversity' and 'inclusion' (which can often place emphasis on provision, visibility and tokenism, sometimes for commercial reasons) within a narrative of 'trust building' (which is something altogether more humanist and substantive). We suggest such an approach because the traditional way that many learn to 'trust' football terraces to be safe spaces, via local/familial histories, is less salient for BAME fans. In order to garner trust, the perceptions of BAME fans need to be valued and considered in future policies and interventions, which means the 'there is no racism in football' and 'be grateful it is not like Eastern Europe'-type responses are not used to rebut the lived experience of 'race' and football fandom. In short, the disconnect between the governance and policy terrain (i.e. 'everyone is welcome') and the lived experience of BAME fans ('some people are more welcome than others') can only be addressed if 'race' is acknowledged overtly as a salient factor in shaping, what neoliberal discourses might term, the 'fan/customer experience'.

Finally, not only must those policy actors working in football take heed of this, football and sport policy scholars are also well advised to take up this challenge, in order to add new intersectional insight into the operation of football as a sociological enterprise. All too often, how fandom and oppressions are inflected through either gender, 'race', sexuality and disability, or all of these modalities, is overlooked. To be clear, it was beyond the scope of this paper to delve in at all of these intersections; we have however, via the adoption of 'race' as an analytical concept, strengthened the case for more research of the intersectional kind to be done, above and beyond what we have been able to do throughout this paper. Therefore, we wish to conclude by calling on others in the field to take up this important challenge and to speak to how social positionality impacts on the lived experience of football and football fandom to avoid further marginalising the experiences of minority fans of all kinds.

\section{References}

Adler, E.S. and Clark, R., 2014. An invitation to social research: how it's done. 5th. Connecticut: Cengage Learning. Ahmad, A., 2011. British football: where are the muslim female footballers? Exploring the connections between gender, ethnicity and Islam. Soccer and Society, 12 (3), 443-456. doi:10.1080/14660970.2011.568110

Ahmed, S., 2000. Embodying strangers. In: A. Horner and A. Keane, eds. Body matters: feminism, textuality, corporeality. Manchester: Manchester University Press, 85-95.

Allahar, A., ed., 2005. Ethnicity, class, and nationalism: caribbean and extra-caribbean dimensions. Maryland: Lexington Books.

Andersen, M.L. and Taylor, H.F., 2008. Sociology: understanding a diverse society. 4th. California: Thomson Wadsworth.

Bakan, A.B. and Dua, E., ed., 2014. Theorizing anti-racism: linkages in Marxism and critical race theories. Toronto: University of Toronto Press.

Bale, J., 2000. The changing face of football: stadiums and communities. Soccer and Society, 1 (1), 91-101. doi:10.1080/ 14660970008721251

Barak, G., Leighton, P., and Flavin, J., 2010. Class, race, gender, and crime: the social realities of justice in America. Maryland: Rowman and Littlefield Publishers.

Beccarini, C. and Ferrand, A., 2006. Factors affecting soccer club season ticket holders' satisfaction: the influence of club image and fans' motives. European Sport Management Quarterly, 6 (1), 1-22. doi:10.1080/16184740600799154

Becker, H.S., 1958. Problems of inference and proof in participant observation. American Sociology Review, 23 (6), 652-660. doi:10.2307/2089053

Biscaia, R., et al., 2012. The effects of emotions on football spectators' satisfaction and behavioural intentions. European Sport Management Quarterly, 12 (3), 227-242. doi:10.1080/16184742.2012.679949 
This is an Accepted Manuscript of an article published by Taylor \& Francis in International Journal of Sport Policy and Politics on 17/07/2019, available online: http://www.tandfonline.com/10.1080/19406940.2019.1627481.

Bradbury, S., Van Sterkenburg, J., and Mignon, P., 2018. The under-representation and experiences of elite level minority coaches in professional football in England, France and the Netherlands. International review for the sociology of sport, 53 (3), 313-334.

Burdsey, D., 2004. Obstacle race? 'Race', racism and the recruitment of British Asian professional footballers. Patterns of prejudice, 38 (3), 279-299. doi:10.1080/0031322042000250466

Burdsey, D., 2006. British Asians and football: culture, identity, exclusion. London: Routledge.

Burdsey, D., 2011. That joke isn't funny anymore: racial microaggressions, colour-blind ideology and the mitigation of racism in English men's first-class cricket. Sociology of sport journal, 28 (3), 261-283. doi:10.1123/ssj.28.3.261

Burdsey, D. and Randhawa, K., 2012. How can professional football clubs create welcoming and inclusive stadia for British Asian fans? Journal of policy research in tourism, leisure and events, 4 (1), 105-111. doi:10.1080/ 19407963.2011.643060

Carrington, B., 1998. New lads, new racism. In: A. Brown, ed.. Fanatics!: power, identity, and fandom in football. London: Psychology Press, 106-112.

Carrington, B., 2004. Introduction: race/nation/sport. Leisure studies, 23 (1), 1-3. doi:10.1080/0261436042000182272

Carrington, B. and McDonald, I., ed., 2002. Race', sport and British society. London: Routledge.

Cashmore, E. and Dixon, K., ed., 2016. Studying football. London: Routledge.

Census, 2011. Office for National statistics: socioeconomic status: ethnicity in the UK [online]. Accessed 19 October 2018. Available at: https://www.ethnicity-facts-figures.service.gov.uk/british-population/demographics/socioeconomicstatus/latest.

Cleland, J. and Cashmore, E., 2014. Fans, racism and British football in the twenty-first Century: the existence of a 'colour-blind 'ideology. Journal of ethnic and migration studies, 40 (4), 638-654. doi:10.1080/1369183X.2013.777524

Cleland, J. and Cashmore, E., 2016. Football fans' views of violence in British football: evidence of a sanitized and gentrified culture. Journal of sport and social issues, 40 (2), 124-142. doi:10.1177/0193723515615177

Cole, M., 2017. Critical race theory and education: a marxist response. New York: Palgrave Macmillan.

Collins, T., 2013. Sport in capitalist society: a short history. London: Routledge.

Crawford, G., 2004. Consuming sport: fans, sport and culture. International journal of sports marketing and sponsorship, 6 (2), 47-62. doi:10.1108/IJSMS-06-02-2004-B007

Darnell, S.C., 2010. Power, politics and "sport for development and peace": investigating the utility of sport for international development. Sociology of sport journal, 27 (1), 54-75. doi:10.1123/ssj.27.1.54

De Kosnik, A. and Carrington, A., 2019. Fans of color, fandoms of color. Transformatve works and culture, 29, 1.

Delgado, R. and Stefancic, J., 2000. Critical race theory: the cutting edge. 2nd. Philadelphia: Temple University Press.

DeWalt, K.M. and DeWalt, B.R., 2011. Participant observation: a guide for fieldworkers. 2nd. Plymouth: Rowman Altamira.

Donnelly, P., et al., 2011. Sport for development and peace: a public sociology perspective. Third world quarterly, 32 (3), 589-601. doi:10.1080/01436597.2011.573947

Eden, C., 2017. Gender, education and work: inequalities and intersectionality. London: Taylor and Francis.

Edensor, T., 2015. Producing atmospheres at the match: fan cultures, commercialisation and mood management in english football. Emotion, space and society, 15, 82-89. doi:10.1016/j.emospa.2013.12.010

Equality and Human Rights Commission. 2008. Equality group inequalities in education, employment and earnings: a research review and analysis of trends over time [online]. Accessed 19 October 2018. Available at: https://www. equalityhumanrights.com/sites/default/files/research-report-10-equality-group-inequalities-in-educationemployment-and-earnings.pdf

Gibbons, T., 2016. English national identity and football fan culture: who are ya? London: Routledge.

Gilroy, P., 1998. Race ends here. Ethnic racial studies, 21 (5), 838-847. doi:10.1080/014198798329676

Giulianotti, R., 1999. Hooligans and carnival fans: scottish football supporter cultures. In: G. Armstrong, ed.. Football cultures and identities. London: Palgrave Macmillan, 29-40.

Giulianotti, R., 2002. Supporters, followers, fans, and flaneurs: A taxonomy of spectator identities in football. Journal of sport and social issues, 26 (1), 25-46. doi:10.1177/0193723502261003

Harris, A.P., 2015. Critical race theory. In: J.D. Wright, ed. International encyclopedia of the social and behavioral sciences. 2nd ed. Amsterdam: Elsevier, 266-270.

Harris, C., 1993. Whiteness as property. Harvard law review, 106 (8), 1707-1791. doi:10.2307/1341787

Hartlep, N., 2011. Going public: critical race theory and issues of social justice. Oklahoma: Tate Publishing.

Hiraldo, P., 2010. The role of critical race theory in higher education. The vermont connection, 31 (1), 7.

Horne, J., Tomlinson, A., and Whannel, G., 1999. Understanding sport: an introduction to the sociological and cultural analysis of sport. London: Taylor and Francis.

Howard, T.C., 2008. Who really cares? The disenfranchisement of African American males in preK-12 schools: A critical race theory perspective. Teachers college record, 110 (5), 954-985.

Hoy, M., 1994. Joyful mayhem: bakhtin, football songs, and the carnivalesque. Text and performance quarterly, 14 (4), 289-304. doi:10.1080/10462939409366091

Hughson, J., et al., ed., 2016. Routledge handbook of football studies. New York: Routledge.

Hylton, K., 2005. 'Race', sport and leisure: lessons from critical race theory. Leisure studies, 24 (1), 81-98. doi:10.1080/ 02614360412331313494 
This is an Accepted Manuscript of an article published by Taylor \& Francis in International Journal of Sport Policy and Politics on 17/07/2019, available online: http://www.tandfonline.com/10.1080/19406940.2019.1627481.

Hylton, K., 2018. Contesting 'Race' and sport: shaming the colour line. London: Routledge.

Karakaya, F., Yannopoulos, P., and Kefalaki, M., 2016. Factors impacting the decision to attend soccer games: an exploratory study. Sport, business and management: an international journal, 6 (3), 320-340. doi:10.1108/SBM-052014-0024

Kassimeris, C., 2007. European football in black and white: tackling racism in football. Maryland: Lexington.

Kernohan, A., 1998. Liberalism, equality, and cultural oppression. Cambridge: Cambridge University Press.

Kidd, B., 2008. A new social movement: sport for development and peace. Sport in society, 11 (4), 370-380. doi:10.1080/17430430802019268

Kilvington, D., 2016. British Asians, exclusion and the football industry. London: Routledge.

Kilvington, D., 2017. British Asians and football: exploring the rise, popularity and significance of Punjabi and Bangla fan groups. In: D. Hassan and C. Acton, eds. Sport and Contested Identities. London: Routledge, 74-89.

Kymlicka, W., 2013. Neoliberal multiculturalism. In: P. Hall and M. Lamont, eds. Social resilience in the neoliberal era. Cambridge: Cambridge University Press, 99-125.

Ladson-Billings, G. and Tate, W.F., IV, 1995. Toward a critical race theory of education. Teachers college record, 97 (1), $47-68$.

Lawrence, S., 2016. 'We are the boys from the Black Country'(Re) Imagining local, regional and spectator identities through fandom at walsall football club. Social and cultural geography, 17 (2), 282-299. doi:10.1080/ 14649365.2015 .1059481

Lawrence, S. 2017. A critical race theory analysis of the English Premier League: Confronting the declining significance of "race"and racism myth. In: The English Premier League. Routledge, 147-163.

Lawrence, S. and Crawford, G., 2019. The hyperdigitalization of football cultures. In: S. Lawrence and G. Crawford, eds. Digital football cultures. London: Routledge, 1-16.

Leddy-Owen, C., 2014. Reimagining englishness: 'race', class, progressive english identities and disrupted english communities. Sociology, 48 (6), 1123-1138. doi:10.1177/0038038513516829

Long, J., et al., 2009. Systematic review of the literature on black and minority ethnic communities in sport and physical recreation. Leeds: Carnegie Research Institute, Leeds Metropolitan University.

Long, J. and Hylton, K., 2002. Shades of white: an examination of whiteness in sport. Leisure studies, 21 (2), 87-103. doi: $10.1080 / 02614360210152575$

Mahony, D.F. and Howard, D.A., 1998. The impact of attitudes on the behavioural intentions of sport spectators. International sports journal, 2 (2), 96-110.

Martinez, D. and Mukharji, P.B., 2013. Football: from England to the world. London: Routledge.

Martone, E., 2008. Encyclopedia of blacks in European history and culture. Greenwood: Connecticut.

Monette, D.R., Sullivan, T.J., and DeJong, C.R., 2013. Applied social research: a tool for the human services. 8th. California: Brooks-Cole.

Picca, L.H. and Feagin, J.R., 2007. Two-faced racism: whites in the backstage and frontstage. New York: Routledge.

Race Disparity Audit. 2017. GOV: society and culture: research and analysis [online]. Accessed 11 October 2018. Available at: https://www.gov.uk/government/publications/race-disparity-audit.

Ramsay, M., 2004. What's wrong with Liberalism?: a radical critique of Liberal philosophy. London: A and C Black.

Ratna, A., 2011. 'Who wants to make aloo gobi when you can bend it like Beckham? 'British Asian females and their racialised experiences of gender and identity in women's football. Soccer and society, 12 (3), 382-401. doi:10.1080/ 14660970.2011 .568105

Ratna, A., 2014. 'Who are ya?'The national identities and belongings of British Asian football fans. Patterns of prejudice, 48 (3), 286-308. doi:10.1080/0031322X.2014.927603

Robson, G., 2000. Millwall football club: masculinity, race, and belonging. In: S.R. Munt, ed.. Cultural studies and the working class. London: Bloomsbury Publishing, 220-222.

Singh, Y.K. and Nath, R., 2006. Fundamental of research methodology and statistics. Delhi: New Age International.

Solorzano, D. and Bernal, D., 2001. Examining transformational resistance through a critical race and LatCrit theory framework: chicana and chicano students in an urban context. Urban education, 36 (3), 308-342. doi:10.1177/ 0042085901363002

Solorzano, D., Ceja, M., and Yosso, T., 2000. Critical race theory, racial microaggressions, and campus racial climate: the experiences of African American college students. Journal of Negro Education, 69(1/2), 60-73.

Solórzano, D.G., 1998. Critical race theory, race and gender microaggressions, and the experience of Chicana and Chicano scholars. International journal of qualitative studies in education, 11 (1), 121-136. doi:10.1080/ 095183998236926

Solórzano, D.G. and Yosso, T.J., 2002. Critical race methodology: counter-storytelling as an analytical framework for education research. Qualitative inquiry, 8 (1), 23-44. doi:10.1177/107780040200800103

Staurowsky, E.J., 2004. Piercing the veil of amateurism: commercialisation, corruption and US college sports. In: T. Slack, ed.. The commercialisation of sport. London: Routledge, 143.

Tapp, A., 2004. The loyalty of football fans-we'll support you evermore? Journal of database management, 11 (3), 203-396. 
This is an Accepted Manuscript of an article published by Taylor \& Francis in International Journal of Sport Policy and Politics on 17/07/2019, available online: http://www.tandfonline.com/10.1080/19406940.2019.1627481.

Taylor, S.J., Bogdan, R., and DeVault, M., 2015. Introduction to qualitative research methods: A guidebook and resource. New Jersey: John Wiley and Sons.

Turner, M., 2013. Modern 'live' football: moving from the panoptican gaze to the performative, virtual and carnivalesque. Sport in Society, 16 (1), 85-93. doi:10.1080/17430437.2012.690404

Wilhelm, J.L., 2018. Atmosphere in the home stadium of hertha BSC (German Bundesliga). Potsdam: Routledge.

Yosso, T.J., 2005. Whose culture has capital? A critical race theory discussion of community cultural wealth. Race ethnicity and education, 8 (1), 69-91. doi:10.1080/1361332052000341006

Zamudio, M., et al., 2011. Critical race theory matters: education and ideology. London: Routledge. 